\title{
THE ARCHITECTURE OF THE CITY: ALDO ROSSI'S NOTION OF PERMANENCE IN A CZECH CONTEXT USING THE EXAMPLE OF THE LETNÁ DEVELOPMENT IN PRAGUE
}

\section{ROSTISLAV STOKLÁSEK}

Brno University of Technology, Faculty of Architecture, Poříćí 5, 63900 Brno, Czech Republic Tutor: doc. Ing. arch. Gabriel Kopáčik, Dr.

Theme of the dissertation: Landscape contexts of the settlements - case studies of selected Czech and Moravian cities

rostislav.stoklasek@gmail.com

\begin{abstract}
By the extent of its observation, Aldo Rossi's notion of permanence, from his book „The Architecture of the City”, shows the potential for its contemporary application.

The paper describes the modern development of Letná using Rossi's concept of permanence. Letná is an area with a well-documented evolution of plans, expectations, and constructions. The paper shows how Rossi's work enables the linking of individual stages of Letná's development, being able to also describe its non-physical artifacts.

This case study analysis proves the usability of the applied terminology for further research on permanence in Czech urban structures.
\end{abstract}

KEY WORDS: Aldo Rossi, permanence, Letná, primary element, monument

\section{Introduction}

With his book The Architecture of the City (1982), Aldo Rossi delivered a valuable contribution to the topic of permanence. A better understanding of permanence in an urban context enables adjustment of the extent of neccessary regulations in urban planning processes (Cavalieri \& Lanza 2020).

The significance of Rossi's ideas lies in the extent of observed phenomenon; his ab- 
straction allows him to find the "urban" created by singular objects in proximity with others through the perception of people. This perception generates a very durable imprint in the collective memory (Rossi 1982).

Nevertheless, the whole theory is presented by examples mostly from ancient Mediterranean cities. Thus, using his theory, this paper sets out to describe a concrete project that is different to Rossi's examples. The goal is to prove the applicability of this theory in a Czech context for its use in further research of permanence in a contemporary Czech urban environment.

\section{Terminology}

The central term of Rossi's theory is an urban artifact, a singular element of a city "characterized by its own history" (Ibid., p. 29). It is not limited to a physical object, but could also mean any historical, structural, geographical, or other element or area of a city (Ibid., p. 22).

Primary elements are urban artifacts that influence their surroundings by earning more significance than their function constitutes. They maintain this significance over time, independent from its function, and act as nuclei of urban processes (Ibid., p. 87).

A monument is for Rossi an extreme form of a primary element by its stability over time, it is a "fix point in urban dynamics, and as such is stronger than economic laws" (Ibid., p. 100).

\section{Case study Letná, Prague}

Despite the fact that Letná is an undeveloped area, its history shows a well-documented and layered evolution of development plans, expectations, and constructions, which makes it ideal for the purpose of this paper. Aligned with Rossi's emphasis on precise analysis, to fully trace its evolution, we must consider also its surrounding urban artifacts.

\section{Ghetto Clearance}

The first modern attempts to develop the area of Letná are directly connected to a project that started at the end of $19^{\text {th }}$ century on the opposite side of the Vltava River. With a vision to align Prague with modern European cities like Paris and Vienna, the city council decided to replace the district of a former Jewish ghetto called Jose- 
fov with a contemporary urban structure consisting of luxury housing along straight boulevards (Bečková 1993, p. 36).

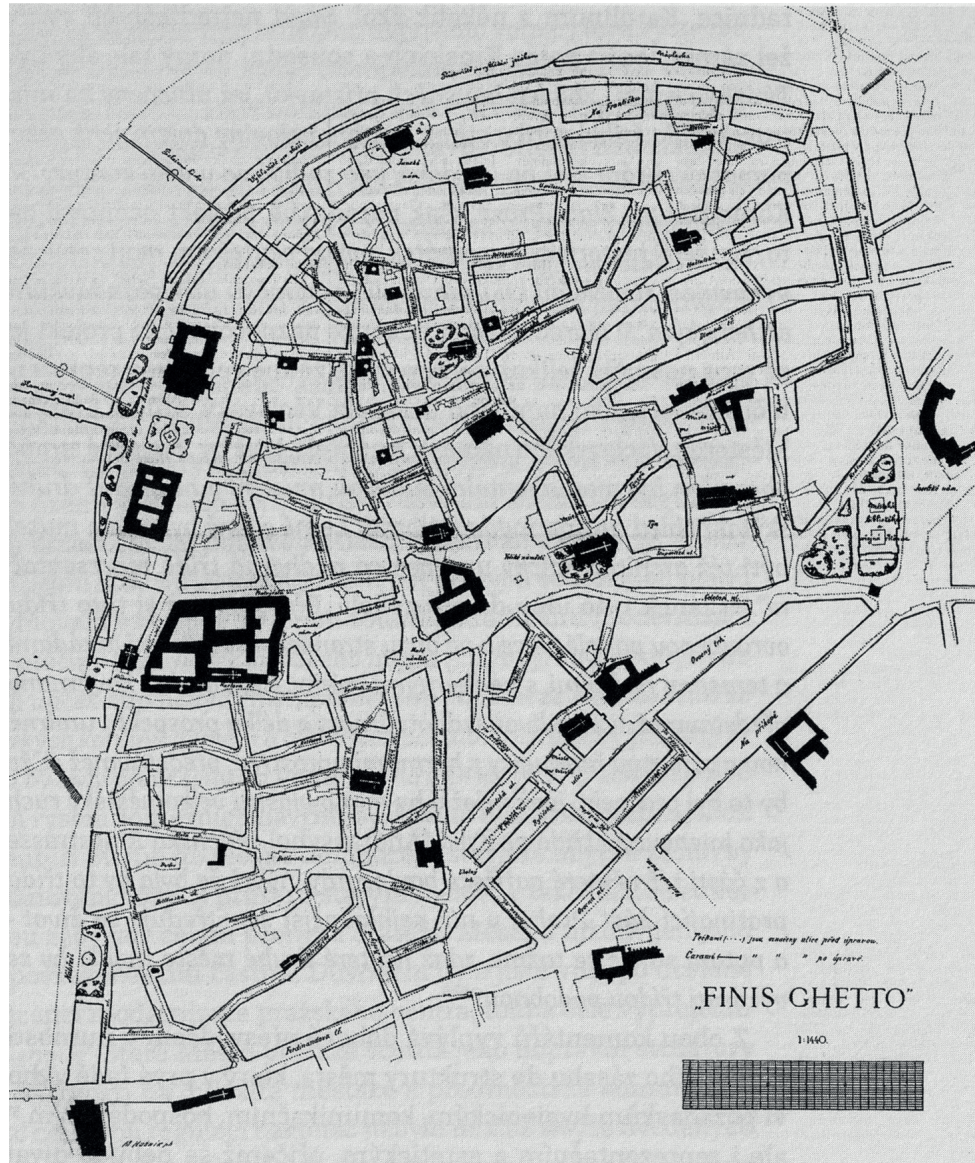

Img. 1. Finis Ghetto - winning proposal for the area of the ghetto (source: Hurtig, Strunc, Hejda, 1887)

A single street in the new urban plan was decisive for the future development of Letná. The rest of the new street layout followed the main axes of the former network, only the Pařížská street was completely independent from any existing spaces and landmarks (Voděra 1993, p. 58-59).

One can immediately find signs of the street becoming a primary element. Through 
its indecisive embedding in the existing structure, forces driving the ideas for subsequent adaptations of its surroundings appeared immediately. There were newspaper articles discussing the need for a more radical breakthrough beyond the Old Town Square all the way to Wenceslaus Square to create a more representative boulevard (Brůhová 2017, p. 23), an idea that reappeared in Letná development competitions at the beginning of the $20^{\text {th }}$ century (Brůhová 2018, p. 202).

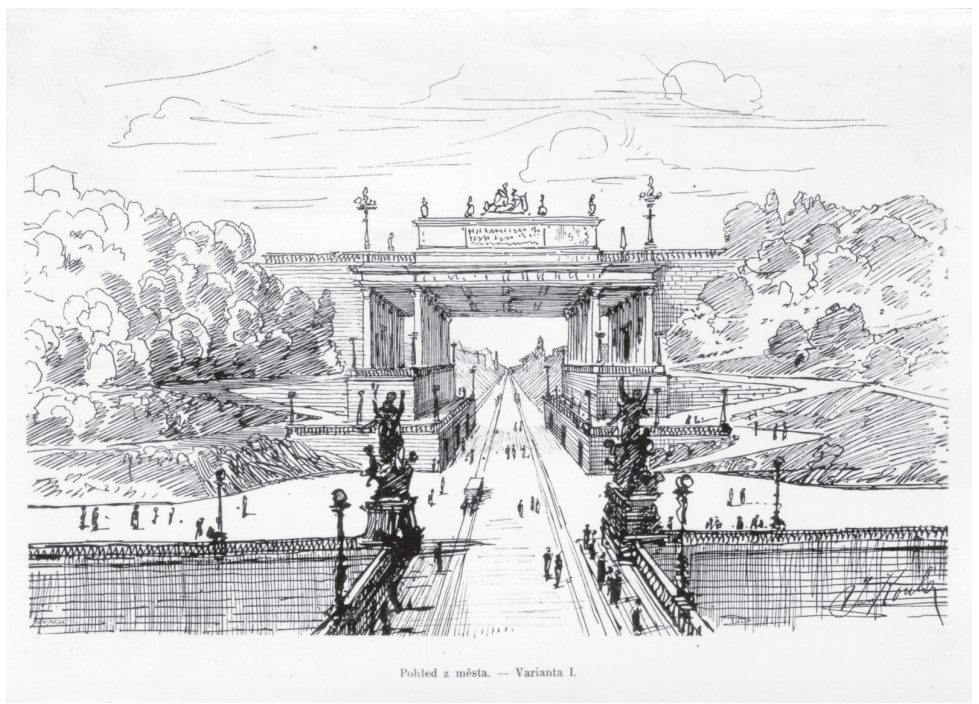

Img. 2. Proposal for the Letná ditch by Jan Koula (source: Koula, 1897)

\section{The Letná ditch}

Even more persistent development plans appeared for the other end of Pařižská street. The abrupt ending on the riverbank triggered a search for an adequate extension across the river (Ibid., p. 185). An artificial ditch through Letná, designed by Jan Koula in 1897, played a decisive role in the discussion. A proposal was made to extend the boulevard through a portal framed ditch in the Letná hill in order to create a direct connection to northern districts. Extreme building costs caused the project to be rejected, yet "the idea succeeded in drawing major public attention and unleashing discussions in the years and decades to come" (Ibid., p. 187).

At that time both extension proposals were aligned with Prague's traffic concept, where the main north-south connection lead through the city centre (Ibid., p. 185), meaning both proposals were supported by functional necessity. 
In the following years, several competitions (1901, 1909, 1920, 1928, 1929/1930) dealt with the development of Letná (Ibid., p. 187-213). Loyal to Koula’s idea, the first results oscillated between the financially unreachable idea of the ditch and the more sensible, yet not so attractive, idea of a tunnel.

A turning point was the competition in 1920. Several projects proposed a new traffic concept with a balanced distribution of the increasing traffic into streets circling the city centre and thus saving the Old Town Square from expected congestion. By 1924, this idea was anchored in regulatory documents, although influential voices from the professional public still preferred the original idea of a monumental extension of the boulevard. The competition of 1928 was expected to enhance this new concept. Nevertheless, some of the participants still presented (and even received an honourable mention) a proposal for a ditch or a tunnel, an idea already unprogressive at that time (Ibid., 203-210).

The presented evolution of Koula's original idea shows how it earned public attention over several decades, and what is even more extraordinary, persisted even beyond its functional justification. This leads us to consider it a separate primary element in the development of Letná, because the idea of the ditch not only became a "catalyst... that rapidly took on a more significant value", but also "disconnected from its original function" (Rossi 1982, p. 87). Significant in the study of permanence is the fact that this non-physical primary element illustrates the broad scale of forms primary elements adopt, just as Rossi observed: "Frequently, they are not even physical, constructed, measurable artifacts; for example, sometimes the importance of an event itself 'gives place' to spatial transformation of a site" (Ibid.).

\section{The Stalin Monument}

Even after all attempts to develop Letná had faded, the boulevard still played its role as a primary element by marking a specific spot on a monotonous hillside of Letná.

Independent from former Letná development projects, the idea to erect a statue of Stalin in Prague appeared in 1949. To make the monument properly visible, an elevated location above the river was chosen (Píchová 2014, p. 23), in the end directly in the axis of Pařížská street, among other reasons also due to its representative character (Ibid., p. 53). The monument was finished in 1955. The decision to remove it came in 1962 after Stalin's cult was abandoned (Ibid., p. 105)

It is an example of the power a monument gains over its location as a "fix point in urban dynamics" (Rossi 1982, p. 100), that the location is still referred to as "Stalin" (Píchová 2014, p. 9), although the statue disappeared almost 60 years ago. 


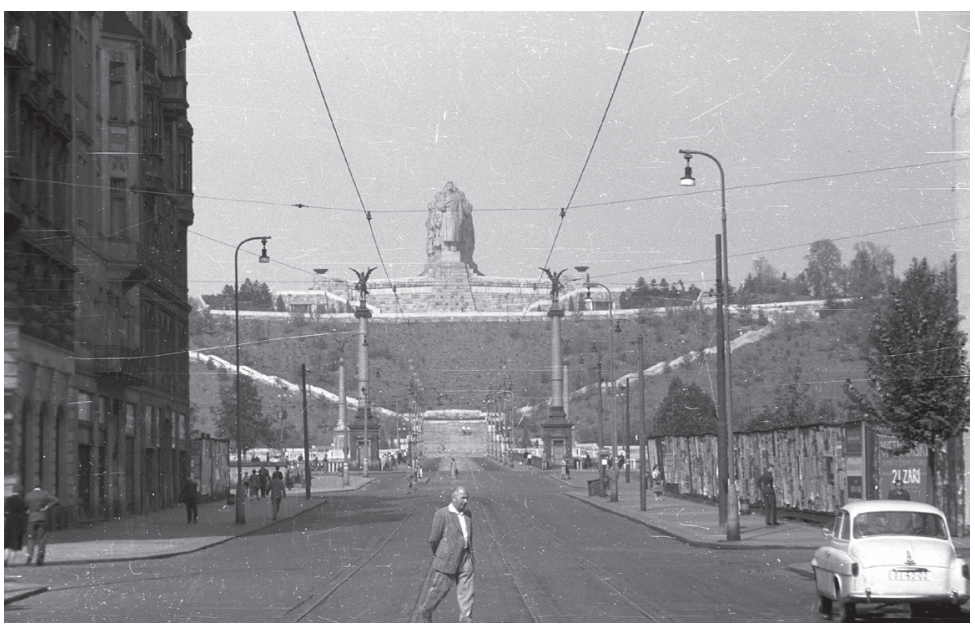

Img. 3. Stalin monument (source: Fortepan / Nagy Gyula)

Memories of the place are still marked by this event, yet we cannot consider the image it has in our collective memory a static representation of a historical situation. One of the most important notions of Rossi's - history becoming memory (Eisenman 1982, p. 7) - provides a clearer take on the situation.

By its deconstruction the monument became just a memory, and despite its intriguing consistency it is going to evolve. When the location undergoes significant changes in the future, the memory of a statue will remain "the sign of a place as expressed in form [of the new development]" (Ibid.). And these future artifacts will alter the original memory of the Stalin monument, just as Peter Eisenman observed: "For Rossi, the city is a theatre of human events. This theatre is no longer just a representation; it is a reality. It absorbs events and feelings, and every new event contains within it a memory of the past and a potential memory of the future" (Ibid.).

The non-physical presence of the monument in such a clear form presents a great potential for further research of its permanence, and for the observation of future development altering the memory of the place.

\section{Conclusion}

Rossi's theory provides a good toolset for interpreting the lifespan of Letná that goes beyond a purely descriptive approach. It can interpret the individual stages of its life and intertwine them together clearly. There is great potential in its ability to investi- 
gate permanence in non-physical structures.

Further research into the actual applicability of Rossi's notions for scientific purposes in a Czech context should apply his theory on multiple projects in a comparative study to evaluate its limits and accuracy.

\section{References}

BEČKOVÁ, Kateřina. Asanace - zatracovaný i obdivovaný projekt obce Pražské. In: HRŮZA, Jiří et al. Pražská asanace: k 100 vydání asanačního zákona pro Prahu. Praha: Muzeum hlavního města Prahy, 1993, p. 35-56. Acta Musei Pragensis. ISBN 80-85394-01-4.

BRŮHOVÁ, Klára. Praha nepostavená: vltavské břehy jako urbanistické téma moderní metropole. Praha: Česká technika - nakladatelství ČVUT, 2017. ISBN 97880-01-06155-8.

BRU゚HOVÁ, Klára. Pražské vize: fantastické stavby, které nikdy nevznikly. Praha: Paseka, 2018. ISBN 978-80-7432-897-8.

CAVALIERI, Chiara a Elena Cogato LANZA. Territories in Time: Mapping Palimpsest Horizons. Urban planning [online]. Cogitatio, 2020, 5(2), 94-98 [cit. 2020-1217]. Dostupné z: doi:10.17645/up.v5i2.3385

EISENMAN, Peter. The Houses of Memory: The Texts of Analogy. In: ROSSI, Aldo. The architecture of the city. Cambridge, Massachusetts: Oppositions Books, 1982, p. 3-11. ISBN 978-0-262-68043-1.

PÍCHOVÁ, Hana. Př́ípad Stalin: historická a literární studie Stalinova pomníku v Praze. Řevnice: Arbor vitae, 2014. ISBN 978-80-7467-066-4.

ROSSI, Aldo. The architecture of the city. Cambridge, Massachusetts: Oppositions Books, 1982. ISBN 978-0-262-68043-1.

VODĚRA, Svatopluk. Architektonicko-urbanistické zhodnocení výsledků asanace. In: HRŮZA, Jiří et al. Pražská asanace: k 100 vydání asanačního zákona pro Prahu. Praha: Muzeum hlavního města Prahy, 1993, p. 57-94. Acta Musei Pragensis. ISBN 80-85394-01-4. 